\title{
Assembly of RNA Nanostructures from Double-Crossover Tiles
}

\author{
Jaimie Marie Stewart, Hari K. K. Subramanian, and Elisa Franco 우
}

\begin{abstract}
Artificial self-assembling RNA scaffolds can be produced from many types of RNA motifs that are rationally designed. These scaffolds are of interest as nanoscale organizers, with applications in drug delivery and synthetic cells. Here we describe design strategies, production methods, and imaging of micrometer-sized RNA nanotubes and lattices that assemble from RNA tiles comprising multiple distinct strands.
\end{abstract}

Key words RNA, RNA assembly, RNA nanotubes, RNA lattices

\section{Introduction}

RNA molecules spontaneously fold into a variety of structural motifs due to their base-pairing interactions. In living cells, natural motifs include aptamers, siRNA, miRNA, and ribozymes that can have functional properties such as catalysis and gene regulation. In nanotechnology, folding of artificial RNA molecules has been exploited to design a multitude of artificial scaffolds with demonstrated functionality in biomedical applications such as gene silencing and targeted therapeutic delivery $[1,2]$.

The synthesis of increasingly complex and large artificial RNA scaffolds has been sought after with the goal of building programmable molecular machines and organelles. While the first efforts in this direction take advantage of conserved tertiary motifs [3], recent work has taken inspiration from the success of design methods developed in DNA nanotechnology [4-6]. The tiling approach originally developed for DNA components can be adapted to RNA yielding structures that reach micrometers in size like their DNA counterparts [7-9]. RNA structures demonstrated with this approach include hollow nanotubes, filaments, and lattices, which can be obtained by specifying design parameters of doublecrossover (DX) tiles (Fig. 1) [8,9]. These tiles include three to 
five short, distinct RNA strands that can be assembled either by gel-purification of individual strands followed by annealing or transcription of all strands in one-pot and annealing [8]. While RNA tile components can be expressed and interact inside cells, the formation of lattices and nanotubes in vivo remains challenging to demonstrate [10]. These RNA assemblies show promise as a vehicle for therapeutic delivery [7]. Understanding RNA design principles to build large assemblies will make it possible to build customizable scaffolds for drug delivery and for the spatial arrangement of components in synthetic cells.

Here we provide protocols for the design, production, and imaging of self-assembled RNA structures from RNA DX tile motifs.

\section{Materials}

\subsection{RNA \\ Transcription}

\subsection{Polyacrylamide \\ Gel Components}

2.3 RNA Extraction, Elution, and Precipitation
Nuclease-free water and RNase removal agent (e.g., RNase Zap) are used throughout the Methods.

1. Synthetic PAGE purified template DNA strands from Integrated DNA Technologies (Coralville, IA, USA).

2. $10 \times$ TE buffer: $100 \mathrm{mM}, 10 \mathrm{mM}$ EDTA, pH 8.0 at $25^{\circ} \mathrm{C}$.

3. AmpliScribe ${ }^{\mathrm{TM}}$ T7-Flash ${ }^{\mathrm{TM}}$ Transcription Kit (Lucigen): T7 RNA Polymerase, $10 \times$ Transcription Reaction Buffer, ATP (100 mM), GTP (100 mM), CTP (100 mM), UTP (100 mM), DTT (100 mM), RiboGuard RNase Inhibitor (40 $\mathrm{U} / \mu \mathrm{L})$, nuclease-free water, control template DNA $(0.5 \mu \mathrm{g} / \mu \mathrm{L})$, RNase-free DNase $\mathrm{I}(1 \mathrm{U} / \mu \mathrm{L})$, store at $-20{ }^{\circ} \mathrm{C}$.

1. $10 \times$ TBE buffer: $890 \mathrm{mM}$ Tris-borate, $20 \mathrm{mM}$ ethylenediaminetetraacetic acid (EDTA), $\mathrm{pH} 8.0-8.5$ at $25^{\circ} \mathrm{C}$.

2. Acrylamide/Bis 19:1, 40\% (w/v) solution, store at $5{ }^{\circ} \mathrm{C}$.

3. Disposable gel cassettes.

4. Urea.

5. Ammonium persulfate (APS): $10 \%(\mathrm{w} / \mathrm{v})$ solution in water.

6. $N, N, N^{\prime}, N^{\prime}$-Tetramethylethylenediamine (TEMED), store at $5{ }^{\circ} \mathrm{C}$.

1. Razor blades.

2. Plastic wrap.

3. Aluminum TLC plate, silica gel coated with fluorescent indicator $\mathrm{F}_{254}$.

4. Sodium acetate.

5. Glycogen, store at $-20{ }^{\circ} \mathrm{C}$. 


\subsection{Assembly Buffer Components}

1. Magnesium chloride.

2. $10 \times$ TAE: $400 \mathrm{mM}$ Tris-acetate, and $10 \mathrm{mM}$ EDTA, $\mathrm{pH} 8.5$, store at $25{ }^{\circ} \mathrm{C}$.

\section{Methods}

\subsection{RNA Tile Design}

1. Choose one of the tile designs in Fig. 1 (see Note 1), and choose a set of parameters from Table 1 (see Notes $\mathbf{2}$ and $\mathbf{3}$ ). Using the parameters of choice, the sequence of the RNA strands required for assembly can be designed using the DNA Design Toolbox [11]. While this toolbox is primarily for DNA nanostructure design, it can be used as a first-pass filter to design sequences that do not have bad secondary structures (both intra and inter-strand) at a specified temperature.

2. Confirm the absence of unwanted secondary structures in the designed RNA strands using NUPACK [12].

3. The number of sticky ends can be changed if one needs to tune the melting temperature of the nanotube assembly. Changing
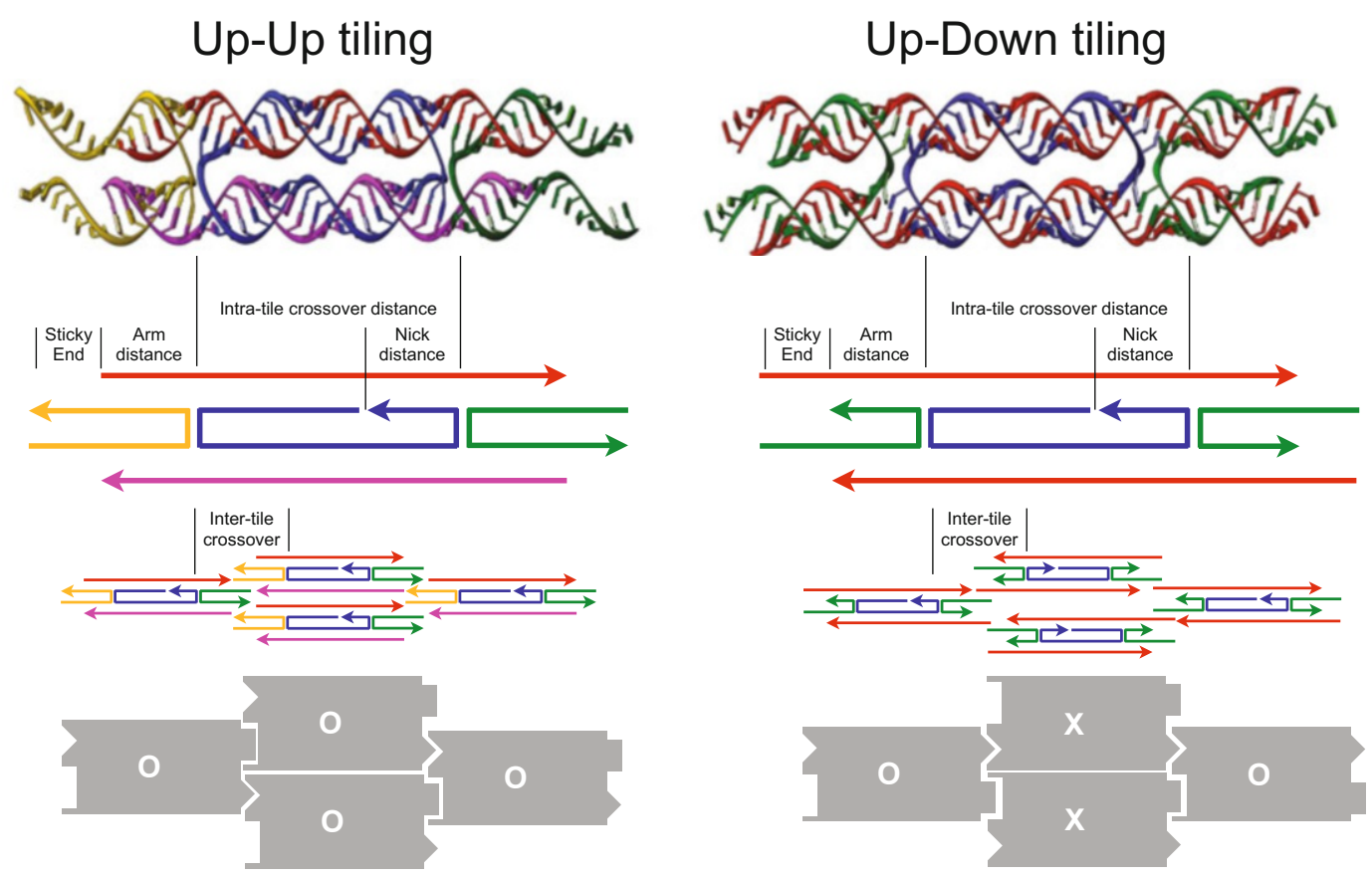

Fig. 1 RNA-based tilings considered in this work. The "up-up" tiling has all the tiles showing the same side up and the "up-down" tiling has every other column of tiles in the assembly showing the same side up. The top row of the figure shows the 3D model of monomer tiles for each tiling. The second row shows an abstraction of the monomer tile that identifies tile domains that influence the assembly outcome. The third row illustrates how the monomers assemble to form an array and the bottom row shows the arrangement of faces of the monomers in the array in each tile type 
Table 1

Parameters for RNA tile designs

\begin{tabular}{|lllllll}
\hline $\begin{array}{l}\text { Tiling } \\
\text { type }\end{array}$ & $\begin{array}{l}\text { Inter-tile crossover } \\
\text { distance }\end{array}$ & $\begin{array}{l}\text { Sticky } \\
\text { end }\end{array}$ & $\begin{array}{l}\text { Nick } \\
\text { distance }\end{array}$ & $\begin{array}{l}\text { Arm } \\
\text { distance }\end{array}$ & $\begin{array}{l}\text { Predominant } \\
\text { structure formed }\end{array}$ & $\begin{array}{l}\text { Avg. nanotube } \\
\text { length }\end{array}$ \\
\hline Up-up & 22 & 6 & 8 & 8 & 2 D arrays & NA \\
\hline Up-up & 23 & 7 & 8 & 8 & Nanotubes & $1.5 \mu \mathrm{m}$ \\
\hline Up-up & 24 & 8 & 8 & 8 & Nanotubes & $1.5 \mu \mathrm{m}$ \\
\hline $\begin{array}{l}\text { Up-up } \\
25\end{array}$ & 9 & 8 & 8 & 2D filaments & NA \\
$\begin{array}{c}\text { Up-up } \\
\text { 26 }\end{array}$ & 10 & 8 & 8 & 2D filaments & NA \\
$\begin{array}{c}\text { Up- } \\
\text { down }\end{array}$ & 28 & 5 & 9 & 11 & Nanotubes & $0.5 \mu \mathrm{m}$ \\
$\begin{array}{c}\text { Up- } \\
\text { down }\end{array}$ & 28 & 5 & 13 & 11 & Nanotubes & $0.5 \mu \mathrm{m}$ \\
$\begin{array}{c}\text { Up- } \\
\text { down }\end{array}$ & 28 & 5 & 11 & 11 & No structures & NA \\
\hline
\end{tabular}

sticky-end length without adjusting any other design parameter will change the inter-tile crossover distance and result in different types of structures formed as shown in Table 1.

4. If parameters not listed in Table 1 are going to be tried, it is important to build 3D computer model of the design to ensure that the crossovers positions provided work with the A-form geometry of the RNA-RNA duplex (see Note 4). The angle with which the bases tilt with respect to the central helical axis can make crossovers at some pairs of positions impossible [4]. A $2 \mathrm{D}$ line drawing as shown in Fig. I does not capture this detail so a $3 \mathrm{D}$ computer model is needed.

5. RNA needed for the assembly can either be purchased directly from a vendor or instead the DNA needed for in vitro transcription of RNA strands can be purchased from a vendor. RNA synthesis by in vitro transcription can be done as described in Subheadings 3.5 and 3.6. The DNA templates will be ordered with a T7 RNA polymerase promoter [7].

3.2 DNA and RNA Quantitation
UV absorbance quantifies nucleic acids by measuring the absorbance of light through a DNA or RNA liquid solution to determine the concentration of molecules.

1. DNA or RNA purchased from the vendor is resuspended in nuclease-free water and vortexed until completely dissolved (see Note 5).

2. Determine the concentration of DNA and RNA by measuring the absorption at $260 \mathrm{~nm}$ according to Beer Lambert's law using sequence-specific extinction coefficients. 


\subsection{Polyacrylamide Gel Electrophoresis (PAGE)}

\subsubsection{Denaturing}

Polyacrylamide gel electrophoresis (PAGE) provides useful information by separating DNA and RNA molecules by their electrophoretic mobility.

Denaturing PAGE separates DNA and RNA molecules based on size and is used to determine sequence length of strands.

1. Prepare a $100 \mathrm{~mL} \mathrm{8 \% (w/v)} \mathrm{19:1} \mathrm{acrylamide:bis} \mathrm{and} 7 \mathrm{M}$ urea premix solution. Add $42 \mathrm{~g}$ of urea to $25 \mathrm{~mL}$ of nanopure water. Heat the solution until the urea is completely dissolved (see Note 6). Then add $10 \mathrm{~mL}$ of $10 \times \mathrm{TBE}$, and the appropriate volume for the desired polyacrylamide percentage. Typically, we prepare $10 \%$ polyacrylamide gel by adding $25 \mathrm{~mL}$ of the $40 \%$ acrylamide/bis $19: 1$, and then fill the remaining volume to $100 \mathrm{~mL}$.

2. Cast the gel by adding in a $50-\mathrm{mL}$ falcon tube $8 \mathrm{~mL}$ of the premix solution, $48 \mu \mathrm{L}$ 10\% APS, and $3.2 \mu \mathrm{L}$ TEMED. Gently rock the tube avoiding the creation of bubbles.

3. Slowly pour the solution in an upright empty $8 \mathrm{~cm} \times 8 \mathrm{~cm}$ with $1 \mathrm{~mm}$ width cassette.

4. Carefully add the gel comb, avoiding the creation of bubbles.

5. Allow the gel to polymerize for $2 \mathrm{~h}$ ( see Note 8 ).

6. After the gel has polymerized, carefully remove the comb as not to disturb the wells.

7. Rinse the wells with running buffer, $1 \times \mathrm{TBE}$, to remove any residual unpolymerized remains.

8. Place the gel in the electrophoresis chamber and add $1 \times \mathrm{TBE}$ buffer.

9. Prerun the gel at $10 \mathrm{~V} / \mathrm{cm}$ at room temperature or $45^{\circ} \mathrm{C}$ in $1 \times$ TBE for $10 \mathrm{~min}$.

10. Carefully pipette the sample and loading buffer into the wells.

11. Run the gel for 50-60 $\mathrm{min}$ at room temperature or $45^{\circ} \mathrm{C}$.

\subsection{Annealing dsDNA Templates}

1. Dilute PAGE-purified DNA strands in nuclease-free water.

2. Mix the template $(\mathrm{t})$ and non-template $(\mathrm{nt})$ strands at a target concentration of $20 \mu \mathrm{M}$ in a buffer of $10 \mathrm{mM}$ Tris, $20 \mathrm{mM}$ $\mathrm{NaCl}$, and $1 \mathrm{mM}$ EDTA.

3. Apply a heat ramp on a thermocycler or PCR machine. Heat the sample up to $95^{\circ} \mathrm{C}$, holding the maximum temperature for $5 \mathrm{~min}$, and cooling to $20^{\circ} \mathrm{C}$ at a rate of $-1^{\circ} \mathrm{C} / \mathrm{min}$.

1. In a $0.5-\mathrm{mL}$ reaction tube, mix:
(a) $1 \times$ T7-Flash reaction buffer.
(b) $9 \mathrm{mM}$ each NTPs.
(c) $10 \mathrm{mM} \mathrm{DTT}$. 
(d) $1 \mu \mathrm{g}$ DNA template.

(e) 20 units of RiboGuard RNase Inhibitor.

(f) 1 unit of AmpliScribe T7-Flash enzyme solution.

2. Incubate the transcription mixture at $37^{\circ} \mathrm{C}$ for $4 \mathrm{~h}$ (see Note 10).

3. After the transcription reaction, to remove the DNA template, add 1 unit of RNase-free DNase I and incubate at $37^{\circ} \mathrm{C}$ for $10 \mathrm{~min}$.

3.6 RNA Purification Purified RNA can be chemically synthesized and ordered directly from a vendor. Alternatively, one can produce RNA via an enzymatic reaction and purify the RNA.

1. Assemble a transcription mix (typically $20 \mu \mathrm{L}$ ) as described in AmpliScribe $^{\mathrm{TM}}$ T7-Flash ${ }^{\mathrm{TM}}$ Transcription Kit instructions.

2. Incubate the reaction mix at $37^{\circ} \mathrm{C}$ for $4 \mathrm{~h}$.

3. Add $1 \mu \mathrm{L}$ DNase I and incubate at $37^{\circ} \mathrm{C}$ for $10 \mathrm{~min}$ to remove DNA templates.

4. Add equal volume of $2 \times$ denaturing loading buffer, then load it on a $10-15 \%$ denaturing gel.

5. After the run, place an aluminum TLC plate, and silica gel coated with fluorescent indicator F254 and cover with plastic wrap.

6. Crack open the gel cassette and place the gel on the plastic wrap on the aluminum TLC plate.

7. Use a short-wave UV $(\sim 254 \mathrm{~nm})$ light source to observe RNA transcripts in the gel.

8. Excise the RNA bands of interest, and chop them into small gel pieces. Collect the pieces in a $0.5-\mathrm{mL}$ tube, filling about half the tube.

9. Add $350 \mu \mathrm{L}$ of $0.3 \mathrm{M}$ sodium acetate $(\mathrm{pH}: 5.2-5.3)$ to completely submerge the pieces and incubate at $42{ }^{\circ} \mathrm{C}$ overnight.

10. Transfer the supernatant to a fresh tube and add $100 \mu \mathrm{L}$ of the $0.3 \mathrm{M}$ sodium acetate $(\mathrm{pH}: 5.2-5.3)$ to the gel pieces. Vortex the content and transfer the $100 \mu \mathrm{L}$ of buffer to the other $350 \mu \mathrm{L}$ in the fresh $1.5-\mathrm{mL}$ tube.

11. Add $1 \mathrm{~mL}$ of freezer cold ethanol $\left(-20^{\circ} \mathrm{C}\right)$ to the supernatant and $1 \mu \mathrm{L}$ of glycogen $(20 \mu \mathrm{g} / \mu \mathrm{L})$ and vortex.

12. Incubate the sample at $-20{ }^{\circ} \mathrm{C}$ overnight.

13. Spin the tube at $>13,500 \mathrm{rpm}$ at $4{ }^{\circ} \mathrm{C}$ for $15 \mathrm{~min}$ in a centrifuge. 
14. Decant the supernatant with a pipette, then add $500 \mu \mathrm{L}$ of $70 \%$ freezer cold ethanol, and spin $(19,400 \mathrm{rcf})$ at $4{ }^{\circ} \mathrm{C}$ for $5 \mathrm{~min}$.

15. Repeat step $\mathbf{1 4 .}$

16. Remove as much supernatant as you can without disturbing the pellet.

17. Open tubes and place in vacufuge and allow to spin at room temperature for $10 \mathrm{~min}$.

18. Resuspend the pellet in nuclease-free water and determine the concentration.

19. Store extracted and purified RNA at $-20^{\circ} \mathrm{C}$.

3.7 Assembling RNA

Nanotubes by

Standard Anneal
3.8 Assembling RNA

Nanotubes by One-Pot Transcription and Anneal

\subsection{Atomic Force Microscopy}

1. In a $0.5-\mathrm{mL}$ reaction tube, mix:
(a) $1 \times$ TAE.
(b) $12.5 \mathrm{mM} \mathrm{MgCl}_{2}$.
(c) $1 \mu \mathrm{M}$ of each strand.

2. Apply a heat ramp on a thermocycler or PCR machine. Heating the sample up to $70^{\circ} \mathrm{C}$, holding the maximum temperature for $5 \mathrm{~min}$, and cooling to room temperature at a constant rate over $24 \mathrm{~h}$.

1. In a $0.5-\mathrm{mL}$ reaction tube, mix:
(a) $1 \times$ TAE.
(b) $22.5 \mathrm{mM} \mathrm{MgCl}_{2}$.
(c) $2.25 \mathrm{mM}$ of each NTP.
(d) $10 \mathrm{mM} \mathrm{DTT}$.
(e) 1/6 volume dilution of AmpliScribe T7-Flash Enzyme Solution.
(f) $0.5-1 \mu \mathrm{g}$ of each DNA template.

2. Apply a heat ramp on a thermocycler or PCR machine. Incubate the sample at $37^{\circ} \mathrm{C}$ for $15 \mathrm{~min}$, then heat the sample up to $70{ }^{\circ} \mathrm{C}$, holding the maximum temperature for $5 \mathrm{~min}$, and cooling to room temperature at a constant rate over $24 \mathrm{~h}$.

RNA nanotubes can be imaged in buffer with nanometer resolution using atomic force microscopy.

1. Place metal specimen disc on a hot plate and melt a small amount of a hot glue stick.

2. Place a mica disc that has been cut into a square and firmly secure it on the metal specimen disc.

3. Cleave the mica with a piece of tape.

4. Place $5 \mu \mathrm{L}$ of sample on the freshly cleaved mica and allow it to incubate on the surface for $30 \mathrm{~s}$. 
3.10 Fluorescence Microscopy
5. Add $25 \mu \mathrm{L}$ of the sample buffer on top of the sample on the mica.

6. Add $25 \mu \mathrm{L}$ of the sample buffer to the AFM tip.

7. Sharp Nitride Lever (SNL) tips from Bruker with a nominal spring constant of $0.24 \mathrm{~N} / \mathrm{m}$ are used for imaging, with a drive frequency of $9-10 \mathrm{kHz}$ (see Note 12). The AFM data are collected with a Digital Instruments Multimode AFM, equipped with a Nanoscope III controller and quantitated using ImageJ.

1. Add $1-2 \mu \mathrm{L}$ of a fluorescent labeled sample ( see Note 13) on a precleaned coverslip.

2. Carefully place a clean glass slide on the sample on the coverslip.

3. Place one drop of immersion oil on a $60 \times$ oil immersion objective and position the assembled slide on the stage.

4. Select the correct filter and focus on the sample.

5. Images are obtained with a NIKON TI-E inverted fluorescence microscope. Cy3 filter was used to image all tiles with $\mathrm{Cy} 3$ labeled S3 strand. A $60 \times$ oil immersion objective is used to collect all images, with a standard exposure time of $600 \mathrm{~ms}$.

\section{Notes}

1. There are two DX tile designs that have been shown to produce nanostructures. Figure 1 shows their $3 \mathrm{D}$ structure, strand composition, and tiling pattern. The "up-up" tiling system self-assembles with all the monomers having the same side up. The "up-down" tiling system self-assembles with tiles alternatingly facing up and down as shown in Fig. 1. For "up-up" tiling systems, monomer tiles with five unique strands have been shown to work [9]. For "up-down" tiling systems, monomer tiles with as low as three unique strands have been shown to work [8]. While the "up-down" design is more parsimonious with only three distinct strands, the "up-down" tiling designs are more versatile both in terms of the number of uniquely modifiable strands and resultant morphologies.

2. The important parameters to determine before the start of the design are: (a) inter-tile crossover distance, (b) sticky-end length, (c) nick distance, and (d) arm distance. These parameters are shown in Fig. 2.

3 . Table 1 shows the resulting nanostructures and their characteristics based on the choice of the parameters listed above. Choose the tiling type and parameter values depending on the type and characteristics of nanostructures desired. The parameter combinations not listed in this table have not yet been tested. 

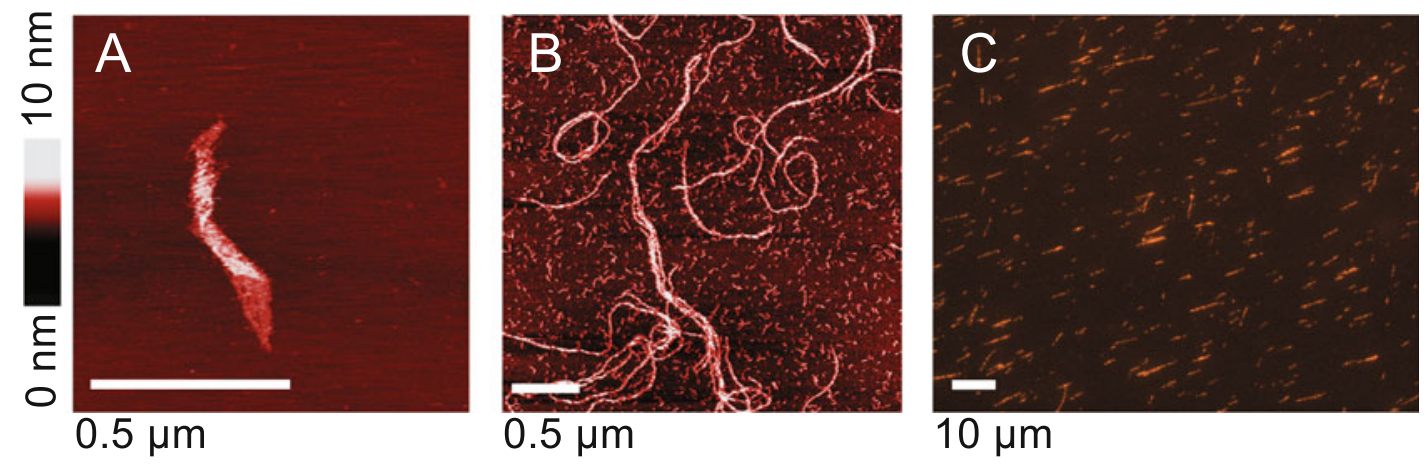

Fig. 2 Example AFM and fluorescence microscopy images of RNA tile-based assemblies. (a) AFM image of up-down tile assembly. (b) AFM image of up-up tile assembly. (c) Representative fluorescence microscopy image of up-up tile assembly

4. Multiple tools are available to build 3D models: (a) PDB models can be built using NAMOT software [13] and edited and rendered using Chimera software [14]. (b) You can also build PDB models using simRNA [15] and export the PDB file to oxDNA $[16,17]$ if you want to run simulations with the model. PDB files can be converted to oxDNA using the TacoxDNA server [17]. Additionally, caution should be taken when using the TacoxDNA server for manipulating RNA as it currently does not support the import of uracil bases

5. Lyophilized DNA or RNA can also be resuspended in trisbuffer for longer storage time; however, the downstream application should be taken into account when selecting the storage buffer.

6. To quickly dissolve urea in water, microwave the solution in $10 \mathrm{~s}$ increments, careful not to let the solution boil.

7. Denaturing polyacrylamide premix can be stored at $4{ }^{\circ} \mathrm{C}$ for up to 4 weeks [18].

8. Gels can be cast and stored for later use in buffer wrapped with plastic wrap $4{ }^{\circ} \mathrm{C}$ for up to a week.

9. We recommend using a 10 -basepair dsDNA ladder (Invitrogen) as a size marker and to stain gels with staining solution, SYBR gold (Molecular Probes) for quantitation of DNA and RNA molecules [19].

10. To increase the amount of transcripts produced, the incubation temperature can be changed from $37^{\circ} \mathrm{C}$ to $42^{\circ} \mathrm{C}$.

11. According to the manufacturer, transcription reactions can be scaled linearly to increase yield of RNA products.

12. When imaging via AFM, sometimes samples will aggregate on the mica surface, so you may have to search the surface for the sample. 
13. When preparing fluorescently labeled RNA strands, adding more than $25 \%$ will result in a lack of assemblies or in malformed assemblies. Adding 10\% of fluorescently labeled strands is optimal.

\section{Acknowledgments}

Elisa Franco acknowledges support from the National Science Foundation through the CAREER award DMR 1938194. Jaimie Marie Stewart is a Merck Awardee of the Life Sciences Research Foundation.

\section{References}

1. Jaeger L (2001) TectoRNA: modular assembly units for the construction of RNA nanoobjects. Nucleic Acids Res 29:455-463

2. Afonin KA, Viard M, Koyfman AY et al (2014) Multifunctional RNA nanoparticles. Nano Lett 14:5662-5671

3. Grabow WW, Jaeger L (2014) RNA selfassembly and RNA nanotechnology. Acc Chem Res 47:1871-1880

4. Geary C, Rothemund PWK, Andersen ES (2014) A single-stranded architecture for cotranscriptional folding of RNA nanostructures. Science 345:799-804

5. Han D, Qi X, Myhrvold C et al (2017) Singlestranded DNA and RNA origami. Science 358:1-10

6. Qi X, Zhang F, Su Z et al (2018) Programming molecular topologies from single-stranded nucleic acids. Nat Commun 9:4579

7. Stewart JM, Viard M, Subramanian HKK et al (2016) Programmable RNA microstructures for coordinated delivery of siRNAs. Nanoscale 8:17542-17550

8. Stewart JM, Subramanian HKK, Franco E (2017) Self-assembly of multi-stranded RNA motifs into lattices and tubular structures. Nucleic Acids Res 45:5449-5457

9. Stewart JM, Geary C, Franco E (2019) Design and characterization of RNA nanotubes. ACS Nano 13:5214-5221

10. Delebecque CJ, Lindner AB, Silver PA, Aldaye FA (2011) Organization of intracellular reactions with rationally designed RNA assemblies. Science 333:470-474

11. Dirks RM, Lin M, Winfree E, Pierce NA (2004) Paradigms for computational nucleic acid design. Nucleic Acids Res 32:1392-1403
12. Zadeh JN, Steenberg CD, Bois JS et al (2011) NUPACK: analysis and design of nucleic acid systems. J Comput Chem 32:170-173

13. Tung CS, Carter ES 2nd (1994) Nucleic acid modeling tool (NAMOT): an interactive graphic tool for modeling nucleic acid structures. Comput Appl Biosci 10:427-433

14. Pettersen EF, Goddard TD, Huang CC et al (2004) UCSF chimera-a visualization system for exploratory research and analysis. J Comput Chem 25:1605-1612

15. Boniecki MJ, Lach G, Dawson WK et al (2016) SimRNA: a coarse-grained method for RNA folding simulations and 3D structure prediction. Nucleic Acids Res 44:e63

16. Ouldridge TE, Louis AA, Doye JPK (2010) DNA nanotweezers studied with a coarsegrained model of DNA. Phys Rev Lett 104:178101

17. Suma A, Poppleton E, Matthies M et al (2019) TacoxDNA: a user-friendly web server for simulations of complex DNA structures, from single strands to origami. J Comput Chem 40:2586-2595

18. Lisa M, Albright Barton E, Slatko (2000) Denaturing polyacrylamide gel electrophoresis. Curr Proto in Nucleic Acid Chem 00(1). https://doi.org/10.1002/0471142700. nca03bs00

19. Rabiya S, Tuma Matthew P, Beaudet Xiaokui, Jin Laurie J, Jones Ching-Ying, Cheung Stephen, Yue Victoria L, Singer (1999) Characterization of SYBR gold nucleic acid gel stain: a dye optimized for use with 300-nm ultraviolet transilluminators. Analytic Biochem 268 (2):278-288. https://doi.org/10.1006/abio. 1998.3067 